\title{
Patients' and their families' coping resources at six weeks following back surgery
}

\author{
Päivi K. Leikkola ${ }^{1,2}$, Mika T. Helminen ${ }^{1,3}$, Eija E-M. Paavilainen ${ }^{1,2}$, Päivi M. Åstedt-Kurki ${ }^{1,3}$ \\ 1. University of Tampere, School of Health Sciences, Tampere, Finland. 2. Hospital District of South Ostrobothnia,
} Seinäjoki, Finland. 3. Hospital District of Pirkanmaa, Department of Research Administration, Tampere, Finland.

Correspondence: Päivi K. Leikkola. Address: The Hospital District of South Ostrobothnia, FIN-60220 Seinäjoki, Finland. Email: paivi.leikkola@epshp.fi

Received: October 13, 2013

Accepted: February 6, 2014

Online Published: March 17, 2014

DOI : $10.5430 / c n s . v 2 n 2 p 105$

URL: http://dx.doi.org/10.5430/cns.v2n2p105

\section{Abstract}

Background: New research knowledge of adult back surgery patients’ and family members' coping resources can help promote the development of their family nursing.

Purpose: The purpose of the study was to assess patients' and their family members' coping resources and related factors six weeks after back surgery.

Methods: Quantitative data were collected from 61 patients and 50 family members by structured, self-administered instruments designed to measure their coping.

Results: Important coping resources for patients and their families were found to involve patient's motivation to recover, normalcy of daily life and the whole family's trust in nursing staff. Patients' overall coping was found to be negatively associated with deteriorated health and mood, insecurity regarding future, social isolation and increased problems in family life, whereas family members' overall coping was negatively associated with the patient's poor health status and the family members' social isolation.

Conclusion: Patients' and their families' coping resources are influenced by the patient's health status and motivation to recover, by home circumstances, family relationships and family's trust in nursing staff.

\section{Key words}

Surgical Patient, Family, Coping, Resources

\section{I ntroduction}

A spinal condition may affect the patient's ability to function and work normally ${ }^{[1-7]}$. In Finland, up to $40 \%$ of the days spent on sickness allowance are due to various musculoskeletal conditions ${ }^{[8]}$; in 2006, these conditions accounted for $30 \%$ of the total unemployment pension expenditure ${ }^{[4]}$. Approximately $15 \%$ of back pain patients are unable to work and one in ten patients is in need of surgical treatment ${ }^{[9]}$. The number of back surgical procedures increased by $40 \%$ in Finland in the years 1996-2005. Even though treatment times are shorter nowadays, the number of hospitalization periods has grown ${ }^{[4]}$ and the total health service expenditure for back surgical treatment has increased ${ }^{[5]}$. Osteoarthrosis, which is not only confined to the spinal area, is the most costly musculoskeletal disease to society in Finland ${ }^{[4]}$. In 2004, there were 7335 
hospitalization periods for spinal surgery in Finland. No national statistics are available on the share of men and women ${ }^{[10]}$. Patient participants in this research were adults, who had undergone surgery for disc herniation or spinal stenosis. While the number of surgeries for disc herniation has decreased, spondylosyndesis and surgery for spinal stenosis have continued to become more common ${ }^{[11]}$.

The existing research on back surgical patients has focused on examining the clinical results of surgical treatment ${ }^{[12-16]}$. The few studies that have been conducted from the perspective of back surgical patients deal with patients' experience of pain ${ }^{[2,3,6]}$, their fear of becoming ill again ${ }^{[1]}$, their improved physical function ${ }^{[2,3,6,7]}$, their ability to work ${ }^{[1,2,6]}$ and their postoperative quality of life ${ }^{[5,7]}$. There are few studies on the coping of this specific group of patients and their families, and the knowledge remains fragmented ${ }^{[9,17,18]}$.

\section{Purpose and theoretical background of the study}

The purpose of this study is to describe back surgical patients' and their families' coping resources and related factors at six weeks following the surgery. The resulting knowledge can by useful as a contribution to the development of family nursing. In the present study, family consists of two persons; the patient and one close family member selected by the patient. These persons identify themselves as family members and they are joined together by sharing or emotional closeness ${ }^{[19,20]}$. Coping is defined as an individual's attempts to deal with a factor that is perceived as stressful. Coping is seen as a process which changes over time and situation ${ }^{[21]}$. Coping resources are internal characteristics ${ }^{[22]}$ and each person's coping process is individually constructed ${ }^{[23]}$. This study describes patients' and family members' actions in a situation that calls for a great deal of resources. These include their perceived health, attitudes and self-esteem ${ }^{[22]}$. Overall coping in this research refers to patients' and family membrs' own estimate of their overall coping. Spinal surgery patients are usually prescribed a sick leave of 5-6 weeks, after which they are expected to have recovered. This study focuses on this very period of time.

Earlier research has shown that being hospitalized and undergoing surgery are major life events that cause fear and psychological stress and increase the risk of depression and anxiety ${ }^{[21,24]}$. Surgery is often followed by changes in patients' coping at home and in their relations with family members and relatives. Surgical patients' daily coping is compromised by pain, difficulty to move, inability to work and limitations to free-time activities, all of which may in turn affect their mood and quality of life ${ }^{[9]}$. Family members are also affected. They often experience the postoperative time as stressful and burdensome ${ }^{[25]}$. They, too, have to deal with changes in daily living and social relationships. Tiredness, anxiety and distress have been found to be common among family members. They suffer from being separated from the patient and undergo periods of fear, helplessness and hopelessness. Increased financial difficulty is also frequently reported ${ }^{[26,27]}$. The situation is especially demanding in case of aged patients with impaired cognitive function, whose family members report increased dissatisfaction and stress during patient's recovery ${ }^{[28]}$.

The recovery of patients depends on their age, length of sick leave and on psychosocial factors ${ }^{[29]}$. For example, it has been confirmed that patients' expectations on work return have an influence on pain, sick leave and disability and that their fear-avoidance beliefs contribute to a low quality of life ${ }^{[17]}$. Patients' higher levels of optimism and expectations have been found to result in better perceived quality of life and in work return within a year following surgery ${ }^{[17,30]}$. An association has been demonstrated between active coping and physical recovery from surgery ${ }^{[31]}$. It has also been shown that patients may, despite relatively poor physical recovery, feel that the quality of their life has improved, much the same way as patients with better physical recovery report ${ }^{[31]}$.

In the face of stress and anxiety, both patients and family members engage in their individual coping behaviours ${ }^{\text {[32-34] }}$. Successful postoperative coping, assessed in terms of perceived outcome and health-related quality of life, has been associated with the individual's active efforts to deal with the situation. Adaptive coping, social support as well as a combination of several coping behaviors have been found to be effective ${ }^{[21,24]}$. Patients' interest in coping is translated into active participation in care, which is likely to have a positive outcome on the final recovery outcome ${ }^{[35]}$. Patients have 
been found to cope, for example, by continuing life as normally as possible, step by step. It has also been confirmed that increased self-care regarding physical health reduces patients' anxiety on post-operative days ${ }^{[36,37]}$. In contrast, patients' recovery may be complicated by their reduced life satisfaction and lower situation-specific self-control expectations ${ }^{[18]}$. Family members, on the other hand, have been shown to require support and information on how the patient should act to ensure coping at home ${ }^{[38]}$. With increasingly short hospital stays, family members' tend to expect more from the hospital staff $^{[39]}$.

These background ideas, together with further literature on patients' and their families' coping needs and experiences, formed a foundation for the creation of an instrument, whose purpose was to measure coping and help seek answers for the following research questions.

\section{Research questions}

1) What kind of coping resources did patients and their family members have at six weeks following surgery?

2) Which background factors were associated with patients' and their families' coping resources at six weeks following surgery?

3) In what way were patients' and their families' coping resources associated with their overall coping at six weeks following surgery?

\section{Method}

\subsection{Research design}

This is a cross-sectional observational study. Data were collected from 61 adult back surgical patients and 50 family members in one central hospital in Finland. A new literature-based, self-administered instrument was developed for this purpose. In the results, patients' and family members' responses to background questions and to twelve groups of questions on coping resources as well as their assessment of their overall coping are combined for analysis.

\subsection{I nstrument}

As no suitable instrument or part of instrument was found, a new instrument was developed to measure the coping of patients and family members. This study uses two of the three major parts of the instruments: background factors and patients' and family members' coping resources ${ }^{[40]}$. In addition, patients and family members were presented with a Visual Analogue Scale (VAS), a 10 centimetre long scale with a value range of 0-100. The VAS has been used in earlier research to assess subjective experiences, for example pain, mood, attention, sleep quality, attitude and ability to function. In this study, the patients and family members were asked to mark their assessment of their overall coping after surgery on the scale ${ }^{[41,42]}$.

In the first section of the instrument, background data were collected by questions on the patient's and family member's age, sex, marital status, family, employment, social life and the patient's illness that required surgical treatment. These background factors were later studied for their association with respondents' coping resources. The coping resources section of the instrument is based on earlier research on patients and families experiencing surgery ${ }^{[18,26,37,43]}$ accessed with help of a librarian from the databases Cinahl (102), Cinahlcumulativeindex (174), British Nursing Index- (14), OvidMedline (143), Linda (29) and Medic (15). The literature was searched for results on patients' and their families' coping needs and experiences. This section of the instrument is also based on an earlier pilot study conducted by the author ${ }^{[44]}$. The instrument for patients was formulated first and then modified to produce an instrument for family members. 
The following literature-based constructs were formulated for the instrument: patients' and family members' attitudes towards future, patient's recovery motivation and activity in self-care, normalcy of daily life, patient's and family member's wellbeing, patient's mood changes, insecurity regarding future, deterioration of health, social isolation, fear (of losing the patient) and the increased complications of life together. In this study, these constructs are referred to as components of coping resources. Respondents were asked to use the Likert scale to assess the importance of the above components as constituents of their coping resources, with the option 1 indicating the least and 4 the highest level of importance. There were 2-11 questions per component on the questionnaires. Means were calculated per respondent and per component, but only for components in which a minimum of $80 \%$ of the items had been responded to. In the assessment of overall coping (VAS), scores above 50 were considered to indicate better overall coping.

\subsection{Validity and reliability}

Both pre-testing and expert panel consultation were used to ensure content validity of the instruments. The expert panel, which consisted of three members with expertise in research, assessed the face validity of each instrument respectively. The experts were consulted to ensure that the instrument contents and questions were clear and comprehensible and that the time given to prospective participants was adequate. Following this, both instruments were tested and commented on by ten health care professionals. The content validity index was 0.88 for the patient instrument and 0.87 for the family member instrument. Both values are good ${ }^{[45]}$.

A reliability assessment was also conducted to determine the extent to which the instrument measured what it was intended to measure and to assess instrument reliability, stability and internal consistency ${ }^{[46]}$. The Cronbach alpha scores ranged from 0.43 to 0.90 for patients and from 0.13 to 0.89 for family members. In both instruments, the following components showed poorer consistency than the others: activity in self care (patient $\alpha=0.56$, family member $\alpha=0.13$ ); normalcy of daily life (patient $\alpha=0.67$, family member $\alpha=0.21$ ) and social isolation (patient $\alpha=0.43$, family member $\alpha=0.22$ ). Furthermore, two components in the family member instrument proved to have poor internal consistency: attitude towards future ( $\alpha=0.57)$ and patient's and family member's wellbeing $(\alpha=0.65)$. The problem may be due to the small number of questions (2-7) within these components. Second, the time passed since surgery may have resulted in the partly poor internal consistency of the family members' instrument, because the patient's health may already have improved considerably. The respondents may have felt that the questions concerned family members of patients who are in a poorer condition. The parallel-forms method could not be used in testing reliability, as no suitable alternative instrument was available. A test-retest analysis was ruled out because the phenomena to be examined were not expected to remain stable over time ${ }^{[47]}$.

Finally, the instrument was pretested in a pilot study conducted by the author ${ }^{[40]}$ prior to the present study with patients $(\mathrm{N}=30)$ and family members $(\mathrm{N}=30)$ selected by patients. For the pilot study, questionnaires and covering letters were handed to patients and family members in one hospital during two months in 2008 and returned, together with consent forms, to the investigator by post. The analysis involved a study of frequencies, distributions, means, standard deviations and correlation. There was no need to make amendments in the questionnaires. Data from the pilot study were not included in the material of the present study.

\subsection{Sample}

The inclusion criteria for participants, both patients and family members, included: age 18 or older, Finnish speaking, aware of the study objectives and capable of responding to the questionnaire. The patients had received surgical treatment for disc herniation or spinal stenosis and they had been cared for on neurosurgical or orthopaedic wards in a central hospital in Finland. The family members were selected and recruited by patients. National statistics were first studied to learn the total number of target group patients in Finland and a statistician was consulted to help assess how much time (two years) would be required to obtain an adequate sample. Data collection was ended after two years. No power analysis was conducted. The data were collected between May 2008 and August 2010. The questionnaires, along with the Visual Analog Scales, were mailed to prospective participants. The initial target group consisted of 126 patients and 126 family 
members, of whom 61 patients (response rate 48\%) and 50 family members (response rate 40\%) returned the questionnaire.

Table 1. Patient and family member background data

\begin{tabular}{|c|c|c|c|c|}
\hline \multirow{2}{*}{ Background factors } & \multicolumn{2}{|c|}{ Patient (N=61) } & \multicolumn{2}{|c|}{ Family member(N=50) } \\
\hline & $\mathbf{N}$ & $\%$ & $\mathbf{N}$ & $\%$ \\
\hline \multicolumn{5}{|l|}{ Sex } \\
\hline female & 31 & 51 & 27 & 54 \\
\hline male & 30 & 49 & 23 & 46 \\
\hline \multicolumn{5}{|l|}{ Marital status } \\
\hline single & 5 & 8 & 3 & 6 \\
\hline married/cohabiting & 47 & 77 & 43 & 86 \\
\hline divorced & 7 & 11 & 3 & 6 \\
\hline widowed & 1 & 2 & 1 & 2 \\
\hline missing data & 1 & 2 & -- & -- \\
\hline
\end{tabular}

On earnings-related/disability

pension

yes

application pending

missing data

$\begin{array}{llll}43 & 70 & 40 & 80 \\ 15 & 25 & 6 & 12 \\ 1 & 2 & 1 & 2 \\ 2 & 3 & 3 & 6\end{array}$

\section{Unemployed}

no

yes

missing data

Family members

no children

one or more children

children not living in the same home

Length of sick leave before surgery (response options given)

$$
\begin{aligned}
& \text { 0-3 months } \\
& >3 \text { months } \\
& \text { missing data }
\end{aligned}
$$

\section{Other persistent disease}

no
yes
missing data

\section{First-time operation}

no

yes

5

10

2
8
6
8
8
10

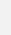

$\begin{array}{ll}40 & 66 \\ 20 & 33 \\ 1 & 1\end{array}$

36

30

66

1

$\begin{array}{ll}15 & 25 \\ 46 & 75\end{array}$

$\begin{array}{lll} & & \\ -- & - \\ -- & - \\ -- & -\end{array}$

$\begin{array}{lll}-- & - \\ -- & - \\ -- & -\end{array}$


Table 1. (Continued.)

\begin{tabular}{|c|c|c|c|c|}
\hline \multirow{2}{*}{ Background factors } & \multicolumn{2}{|c|}{ Patient $(\mathrm{N}=61)$} & \multicolumn{2}{|c|}{ Family member(N=50) } \\
\hline & $\mathbf{N}$ & $\%$ & $\mathbf{N}$ & $\%$ \\
\hline \multicolumn{5}{|l|}{$\begin{array}{l}\text { First time as a family member of patient undergoing } \\
\text { surgery }\end{array}$} \\
\hline no & -- & -- & 28 & 56 \\
\hline yes & -- & -- & 21 & 42 \\
\hline missing data & -- & -- & 1 & 2 \\
\hline \multicolumn{5}{|l|}{ Previous operations (response options given) } \\
\hline none & 13 & 21 & 19 & 38 \\
\hline one or more & 48 & 79 & 29 & 58 \\
\hline missing data & -- & -- & 2 & 4 \\
\hline \multicolumn{5}{|l|}{ Free-time activities } \\
\hline no free-time activities before or after illness & 7 & 11 & -- & -- \\
\hline no free-time activities before or after patient's illness & -- & -- & 7 & 14 \\
\hline had to stop the free-time activities & 21 & 34 & -- & -- \\
\hline irregular pursuit of free-time activities after illness & 24 & 39 & -- & -- \\
\hline $\begin{array}{l}\text { irregular pursuit of free-time activities after patient's } \\
\text { illness }\end{array}$ & -- & -- & 21 & 42 \\
\hline regular free-time activities & 6 & 10 & 20 & 40 \\
\hline missing data & 3 & 5 & 2 & 4 \\
\hline \multicolumn{5}{|l|}{ One or several confidants } \\
\hline no & 1 & 2 & 5 & 10 \\
\hline yes & 60 & 98 & 43 & 86 \\
\hline \multicolumn{5}{|l|}{ Contact with the most significant person } \\
\hline daily & 48 & 79 & 31 & 62 \\
\hline weekly & 9 & 15 & 16 & 32 \\
\hline once a month & 1 & 1 & 1 & 2 \\
\hline missing data & 3 & 5 & 2 & 4 \\
\hline
\end{tabular}

The patients' mean age was 47.7 years (range 18-71) and the family members' 47 years (range 18-77). As shown in Table 1 , a slight majority of respondents were women. Most patients and family members were either married or cohabiting and had one or more children. In both groups, a small minority of respondents were unemployed. All the patients had been on sick leave during the past year, with little variation in the duration of sick leave. Nearly one third of the patients had been diagnosed with another chronic disease. For most patients, this had been their first spinal surgery. A slight majority of family members had previous experience of being a surgical patient's family member, and in both groups, the majority of the respondents had a history of earlier surgical procedures. One third of the patients had been compelled to give up their free-time activities due to their illness, whereas family members had continued to pursue their interests. Both patients and family members had one or several confidants or persons to talk to. Most of them stayed in contact with such close persons on a daily basis.

\subsection{Ethical considerations}

The National Advisory Board on Health Care Ethics principles were observed ${ }^{[48]}$. Participation was voluntary and based on informed consent. The questionnaires were mailed, giving each prospective participant full freedom to decide whether or not to enter the study. All participants were legally competent adults. Tampere University Hospital Ethical Committee 
permission (R07165H) and hospital permission to conduct research were obtained and the anonymity of the respondents ensured.

\subsection{Data analysis}

The Statistical Packages for Social Sciences (SPSS) 18.0 for Windows was used for statistical analysis. Where needed, item scores were reversed to make the values directionally consistent ${ }^{[49]}$. To help describe data and for further analysis, both patients and family members were grouped into two categories of almost equal size: the under 45-year-olds and those 45 or older. The responses to items on respondents' coping resources were scored as follows: strongly disagree $=1$ point, disagree $=2$ points, agree $=3$ points and strongly agree $=4$ points. The results are presented using frequencies, percentages, range, means and medians. Since the data were not normally distributed, non-parametric statistical methods (Mann-Whitney and Kruskal-Wallis Tests) were used to assess relationships between variables ${ }^{[49]}$. Spearman's correlation was also conducted to analyse the association between the groups of questions and assessment of overall coping. A correlation was determined to be significant if the $P$-value was below .05. Because of the limited sample size, missing data has not been complemented or replaced for example by means during the analysis.

Table 2. Patients' and family members' experiences of the components of coping resources

\begin{tabular}{|c|c|c|c|c|c|c|}
\hline Components of coping resources & $\begin{array}{l}\text { Patient } \\
\text { Number }\end{array}$ & Median & $\mathbf{Q}=\mathbf{Q 1 - Q 3}$ & $\begin{array}{l}\text { Family } \\
\text { member } \\
\text { number }\end{array}$ & Median & $\mathbf{Q}=\mathbf{Q 1 - Q 3}$ \\
\hline Attitude towards future & 60 & 3.50 & $3.00-3.80$ & 50 & 3.33 & $3.00-3.53$ \\
\hline Patient's recovery motivation & 60 & 3.75 & $3.06-4.00$ & 48 & 4.00 & $3.50-4.00$ \\
\hline Activity in self-care & 56 & 3.25 & 2.81-3.75 & 46 & 2.88 & $2.50-3.00$ \\
\hline Normalcy of daily life & 58 & 3.50 & $2.50-4.00$ & 50 & 4.00 & $3.50-4.00$ \\
\hline $\begin{array}{l}\text { Patient's and family member's } \\
\text { well-being }\end{array}$ & 59 & 3.00 & $2.71-3.57$ & 50 & 3.21 & $2.82-3.71$ \\
\hline Shared trust in nursing staff & 57 & 3.67 & $3.33-4.00$ & 48 & 4.00 & $3.42-4.00$ \\
\hline Patient’s mood changes & 59 & 1.82 & $1.27-2.27$ & 50 & 1.67 & $1.22-2.14$ \\
\hline Insecurity regarding future * & 52 & 1.83 & $1.00-3.00$ & 44 & 2.17 & $1.00-3.00$ \\
\hline Deterioration of health ${ }^{*}$ & 59 & 2.40 & $1.70-2.90$ & 50 & 1.94 & $1.50-2.72$ \\
\hline Social isolation ${ }^{*}$ & 58 & 2.25 & $1.50-3.00$ & 49 & 1.50 & $1.00-2.50$ \\
\hline Fear (of losing the patient) & 58 & 3.50 & $3.38-4.00$ & 49 & 3.50 & $3.50-4.00$ \\
\hline $\begin{array}{l}\text { Increased complications of life } \\
\text { together }\end{array}$ & 59 & 1.63 & $1.25-2.13$ & 49 & 1.71 & $1.14-2.14$ \\
\hline
\end{tabular}

(Scale 1-4, 4= strongly agree, 3= agree, 2=disagree, 1= strongly disagree).

* Reverse ordering with low values indicating positive meaning

\section{Results}

\subsection{Patients' and family members' coping resources}

As shown in Table 2, it was found that according to patients, the most positive components of their coping resources were recovery motivation, normalcy of daily life and respondents' shared trust in nursing staff. Fear was found to deplete coping resources. Increased complications of life together and changes in the patient's mood, however, were not considered to have any major contribution. Similarly, family members also regarded patient's recovery motivation, normalcy of daily life and shared trust in nursing staff as their most positive coping resources. They found that their fear of losing the patient decreased their coping resources, whereas social isolation due to the patient's illness, the patient's mood changes, 
increased complications of life together and the deterioration of the patient's health did not affect their coping resources significantly.

\subsection{Background factors related to patients' and family members' coping resources}

Comparison by marital status revealed that patients who were separated or divorced experienced more often that increased complications of life together had affected their coping negatively ( $p$-value for the difference .028). In comparison, the median for unmarried patients was 2.50, for married or cohabiting patients 1.50 and for widowed persons 2.86, so there was a significant difference between the groups.

Regardless of their educational background, family members experienced that their attitude towards future had been a positive contribution to their coping resources. The differences between educational groups were practically rather small; the median for family members without any vocational qualification was 3.00, whereas it was 3.25 for those with upper secondary level education, 3.60 for those with a degree or diploma from a university of applied sciences or college and 3.33 for university graduates ( $p=.039$ ). In other words, those with a relatively high education had the highest score.

No major differences were found between educational groups in family members concerning their rating of the patient's self-care activity as a coping resource. The median was 2.50 for family members without a vocational qualification, 2.75 for those with upper secondary level education, 3.00 for university of applied sciences or college graduates and 2.50 for family members with a university degree $(p=.049)$. Again, those with more education, excepting the most highly educated group, found this component slightly more important to their coping than other respondents.

It was found that in patients with an application pending for earnings-related or disability pension, insecurity regarding future had a stronger negative contribution to their coping resources than in other groups. Respondents with an application pending had a median of 4.00, whereas those in working life had a median of 1.33 ( $p=.023)$ and those already pensioned a median of 3.00. In family members, respondents on earnings-related or disability pension felt more strongly (median 3.33) that their insecurity of future had contributed to their coping resources negatively than other groups. Working family members had a median of $1.67(p=.019)$ and family members with an application pending a median of 2.68.

A significant association was found between patients' employment status and insecurity regarding future as a component affecting coping resources. The median for employed people was 1.33, whereas it was 3.00 for unemployed patients $(p=.027)$. Working patients experienced future as more secure than unemployed patients. Furthermore, the unemployed respondents felt slightly more strongly that their social isolation had had a negative contribution to their coping resources. This association between patients' employment status and social isolation was statistically almost significant, with the median of 2.00 for working and 3.00 for unemployed patients $(p=.045)$.

Irrespective of the number of earlier operations, patients regarded their recovery motivation as a positive component of their coping resources. The recovery motivation was more pronounced in the responses of those patients, who had had first-time surgery for their condition compared to patients, who had earlier experience of surgery. The median for the first-time surgery group was 4.00 and for the latter group 3.13 ( $p=.012)$. As regards patients' attitude towards future, those who had had first-time surgery felt more strongly that their attitude had positively affected their coping resources (median 3.50), compared to patients with earlier experience of surgery (median 3.00; $p=.013$ ). As to patients' deterioration of health, it was found to affect coping resources negatively, irrespective of the amount of earlier surgical experience. The first-time surgery patients felt this less strongly. Their median was 2.25, whereas those with previous experience of surgery had a median of $2.89(p=.020)$.

The recovery motivation median for patients who were 45 or older was 3.50, while it was $4.00(p=.019)$ for under 45-year-old patients. This is practically not a very significant difference, but it indicates that the recovery motivation of 
under 45-year-old patients was a slightly stronger positive component of their coping resources. Opposite results were obtained for shared trust in nursing staff; the older age group rated their experiences more positively with a median of 4.00 , whereas the under 45-year-old patients had a median of $3.33(p=.020)$. The under-45-year-old family members rated their future as slightly less insecure (median 1.67) than the older age group, whose median was 2.67 ( $p=.043$ ).

\subsection{Association between patients' and family members' coping resources and overall coping}

Patients' coping at six weeks following surgery was also assessed by studying the association between the VAS overall assessment and the means calculated for each component.

Table 3. Correlation study (Spearman's correlation) on the relationship between component means and patients' and family members' overall assessment of postoperative coping

\begin{tabular}{|c|c|c|c|c|c|c|}
\hline \multirow[b]{2}{*}{ Components of coping resources } & \multicolumn{2}{|c|}{$\mathbf{N}$} & \multicolumn{2}{|c|}{ Correlation } & \multicolumn{2}{|c|}{$P$-value } \\
\hline & Patient & $\begin{array}{l}\text { Family } \\
\text { member }\end{array}$ & Patient & $\begin{array}{l}\text { Family } \\
\text { member }\end{array}$ & Patient & $\begin{array}{l}\text { Family } \\
\text { member }\end{array}$ \\
\hline Attitude towards future & 60 & 50 & .681 & .313 & .000 & .027 \\
\hline Patient's recovery motivation & 60 & 48 & .716 & .309 & .000 & .032 \\
\hline Activity in self-care & 56 & 46 & .292 & .000 & .029 & .999 \\
\hline Normalcy of daily life & 58 & 50 & .595 & .450 & .000 & .001 \\
\hline Patient's and family member's wellbeing & 58 & 50 & .569 & .188 & .000 & .191 \\
\hline Shared trust in nursing staff & 57 & 48 & .330 & .167 & .012 & .256 \\
\hline Patient's mood changes & 59 & 50 & -.720 & -.514 & .000 & .000 \\
\hline Insecurity regarding future & 52 & 44 & -.536 & -.122 & .000 & .430 \\
\hline Deterioration of health & 59 & 50 & -.739 & -.413 & .000 & .003 \\
\hline Social isolation & 58 & 49 & -.677 & -.540 & .000 & .000 \\
\hline Fear (of losing the patient) & 58 & 49 & .295 & .156 & .024 & .283 \\
\hline Increased complications of life together & 59 & 49 & -.617 & -.350 & .000 & .014 \\
\hline
\end{tabular}

In Table 3 statistically significant results $(p<.05)$ are highlighted in bold. The table shows how Spearman's correlation revealed some statistically significant and meaningful differences. The patients who reported poorer mood, more insecure future, deteriorated health, social isolation and increased complications of life together, also rated their overall coping at six weeks following the surgery as poorer than patients with opposite experiences. In contrast, patients with a more positive attitude towards future, higher recovery motivation, experienced normalcy of daily life and shared wellbeing, rated their overall coping as higher at six weeks after the surgery. Family members' assessment of coping was studied by the same method as that of patients. The analysis yielded statistically partly significant and meaningful differences. Most notably, those family members, who reported patient's changeable moods and their own social isolation, rated their overall coping as poorer at six weeks following the patient's surgery.

\section{Discussion}

Changes in family relations or in patients' ability to cope at home are reflected on the whole family's coping resources ${ }^{[9]}$. In the present study, this association was determined in both patients and family members; both felt that the patient's recovery motivation, normalcy of daily life and their shared trust in nursing staff constituted strengthening and positive coping resources. According to Salmenperä et al. ${ }^{[9]}$ patients' mood affects their coping in daily life. The present study had different results; both patients and family members rated the role of patient's mood changes as insignificant at six weeks 
following the surgery.

Kopp et al. ${ }^{[18]}$ suggest that patients' recovery is complicated by their reduced life satisfaction and lower situation-specific self-control expectations. In this study, the effect of life dissatisfaction was apparent in patients who were separated or divorced. They rated high on increased complications of family life, which had a negative contribution to their coping ${ }^{[18]}$. Unemployed patients also reported that their being out of work had very much undermined their coping resources. Finally, patients and family members on earnings-related or disability pension or with an application pending rated their coping resources more poorly than respondents in working life.

It was found that the positive effect of recovery motivation was greatest in first time surgery patients. In contrast, patients' and family members' age did not significantly affect their experience of the patient's recovery motivation, although the role of recovery motivation was slightly stronger in under 45 -year-olds compared to older patients ${ }^{[21,35]}$.

Postoperative stress and strain were evident in family members' insecurity regarding future in both age groups ${ }^{[28]}$. The older family members felt more strongly than those who were under 45 that the insecurity of future threatened their coping resources ${ }^{[25]}$.

Johansson et al. ${ }^{[17]}$, among others, found that cognitive behavioral factors predict pain, disability and quality of life after surgery. The results of this study reveal an association between spine surgical patients' and their family members' coping resources and their overall coping (see Table 3). The association was stronger in patients than in family members. In patients, it occurred especially through experienced mood and health, insecurity regarding future, social isolation and increased complications of life together. In family members, the association was strong with the patient's mood and their own social isolation.

To sum up some of the most important findings of this study: At six weeks after surgery, patients' and their family members' important coping resources involved the patient's recovery motivation, normalcy of daily life and shared trust in nursing staff. Both patients' and family members' coping resources were undermined by the patient's social isolation and by increased complications of their life together. Insecurity regarding future decreased the coping resources of over 45-year-old family members. It was also found that the various components of patients' and family members' coping resources and their overall coping were associated. In patients, this association concerned mood and deterioration of health, insecurity of future, social isolation and increased complications of family life, whereas in family members, it concerned the patient's mood and their own social isolation.

A number of limitations may have affected the research process. Data collection from a single hospital can be regarded as one limitation. Second, nonresponse may have affected sample representativeness. No name lists were kept and it was not possible to determine the exact number of non-responders. The data collection period was already relatively long and the investigators decided against a repeat enquiry. Selection bias may have occurred. Those respondents, who had experienced greater changes in their coping resources may have been more motivated to respond than patients and family members with less changes experienced in coping resources. Furthermore, patient-family member communication may have had an influence on the content of their respective responses. Finally, the high number of comparisons in the study may have increased the risk of type 1 error. Bonferroni correction was not performed. However, considering that postal enquiries are a challenging method of collecting data ${ }^{[50]}$, the sample size can be considered moderate. The results may be valuable despite the limited sample, as there is currently little knowledge of the coping of back surgery patients and their families in the weeks following their discharge.

\section{Conclusion}

The results of this study can be useful to nursing professionals for developing family nursing practice with postoperative 
patients and their family members. In family nursing it is important for patients' and families' postoperative coping that the actions of nursing staff create trust. The staff should seek to improve patients' self-care motivation, which in turn may result in better recovery outcomes. In addition, nursing staff need to take into consideration the patient's family relations and home circumstances. In future research, collecting data of patients' and their families' coping resources over a longer period after surgery would give a more comprehensive picture of this important topic. An interventional study is also indicated to confirm the conclusions of this observational study.

\section{References}

[1] den Boer JJ, Oostendorp RAB, Beems T, Munneke M, Evers, AWM. Reduced work capacity after lumbar disc surgery: the role of cognitive-behavioral and work-related risk factors. Pain. 2006a; 126: 72-78. http://dx.doi.org/10.1016/j.pain.2006.06.010

[2] den Boer JJ, Oostendorp RAB, BeemsT, Munneke, M, Evers AW M. Continued disability and pain after lumbar disc surgery: The role of cognitive-behavioral factors. Pain. 2006b; 123: 45-52. http://dx.doi.org/10.1016/j.pain.2006.02.008

[3] Padua L, Caliandro P, Padua R, et al. Quality of life of patients operated on for lumbar stenosis: a long-term follow-up. Acta Neurochir. 2007; 149: 275-279. http://dx.doi.org/10.1007/s00701-006-1099-4

[4] Pohjolainen T, Seitsalo S, Sund R, Kautiainen H. Mitä selkävaiva maksaa- selkäsairauksien suorat ja epäsuorat kustannukset. [What is the cost of back pain - direct and indirect costs of back conditions]. Suom Ortop Traumat. 2006: 29: 254-258.

[5] Rampersaud YR, Bheesma R, Lewis SJ, Stas V, Barron R, Davey R, Mahomed N. Assessment of health-related quality of life after surgical treatment of focal symptomatic spinal stenosis compared with osteoarthritis of the hip or knee. Spine J. 2007; 8: 296-304. http://dx.doi.org/10.1016/j.spinee.2007.05.003

[6] Saban KL, Penckofer SM, Androwich I, Bryant FB. Health-related quality of life of patients following selected types of lumbar spinal surgery: a pilot study. Health Qual Life Out. 2007; 5: 71. http://dx.doi.org/10.1186/1477-7525-5-71

[7] Slover J, Abdu W, Hanscom, B. The impact of comorbidities on the change in short-form 36 and Oswestry scores following lumbar spine surgery. Spine. 2006; 31(17): 1974-1980. http://dx.doi.org/10.1097/01.brs.0000229252.30903.b9

[8] Viikari-Juntura E, Heliövaara M, Alaranta H. Tuki- ja liikuntaelimistön sairauksien ja vammojen epidemiologia ja ehkäisy[Epidemiology and prevention of musculo-skeletal diseases and injuries]. In Arokoski J, Alaranta H, Pohjolainen T, Salminen, Viikari- Juntura E. Fysiatria. [Physiatrics] 4th ed. Keuruu, Finland: Otava; 2009: p. 28-40.

[9] Salmenperä R, Tulli S, Virta M, editors. Neurologisen ja neurokirurgisen potilaan hoitotyö[Nursing care of the neurological and neurosurgical patient].Tampere, Finland: Tammi; 2002. p. 313-333.

[10] Terveyden ja hyvinvoinnin laitos [National Institute for Health and Welfare] [Internet]; 2006[cited 2006 Aug 11]. Available from: http://www.thl.fi/fi_FI/web/fi/tutkimus/tyokalut/tietokantaraportit

[11] Seitsalo S, Malmivaara A. Kirurgian vaikuttavuus selkäsairauksissa[Effectiveness of surgery for back conditions]. [Internet]. Impakti 6/2005 [cited 2012 Oct 25]. Available from: http://www.stakes.fi/finohta/e-materiaali/

[12] Helenius I, RemesV, Lamberg T, Schlenzka D, Poussa M. Long-term health-related quality of life after surgery for adolescent idiopathic scoliosis and spondylolisthesis. J Bone Joint Surg. 2008; 90:1231-1239. http://dx.doi.org/10.2106/JBJS.G.00114

[13] Ibrahim A, Crockard A, Antonietti P, et al. Does spinal surgery improve the quality of life for those with extradural (spine) osseus metastases: an international multicenter prospective observational study of 223 patients. J Neurosurg-Spine. 2008; 8: $271-278$. http://dx.doi.org/10.3171/SPI/2008/8/3/271

[14] Jagannathan J, Shaffrey CI, Oskouian RJ, et al. Radiographic and clinical outcomes following single-level anterior cervical discectomy and allograft fusion without plate placement or cervical collar. J Neurosurg-Spine. 2008; 8: 420-428. http://dx.doi.org/10.3171/SPI/2008/8/5/420

[15] Starkweather AR, Witek-Janusek J, Nockels RP, et al. The multiple benefits of minimally invasive spinal surgery: Results comparing transforaminal lumbar interbody fusion and posterior lumbar fusion. Journal Neurosci Nurs. 2008; 40(1): 32-39. http://dx.doi.org/10.1097/01376517-200802000-00006

[16] Watanabe K, Hasegawa K, Hirano T, Uchiyama S, Endo N. Evaluation of postoperative residual spinal deformity and patient outcome in idiopathic scoliosis patients in Japan using the Scoliosis Research Society Outcomes Instrument. Spine. 2007; 32(5): 550-554. http://dx.doi.org/10.1097/01.brs.0000256474.68580.f2

[17] Johansson AC, Linton S J, Rosenblad A, Bergkvist L, Nilsson O. A prospective study of cognitive behavioural factors as predictors of pain, disability and quality of life one year after lumbar disc surgery. Disabil Rehabil 2010; 32(7): 521-529. http://dx.doi.org/10.3109/09638280903177243

[18] Kopp M, Bonatti H, Haller C, et al. Life satisfaction and active coping style are important predictors of recovery from surgery. J Psychosom Res. 2003; 55(4): 371-377. http://dx.doi.org/10.1016/S0022-3999(03)00012-6 
[19] Friedman MM, Bowden VR, Jones EG. Family nursing research, theory and practice. 5th ed. Uppersaddleriver, NJ: Pearson education; 2003: p. 35-58.

[20] Åstedt-Kurki P, Jussila AL, Koponen L, Lehto P, Maijala H, Paavilainen R, Potinkara H. Kohti perheen hyvää hoitamista[Towards good nursing care]. Porvoo, Finland: WSOY; 2008. p.11-28.

[21] Hedlund M, Ronne-Engström E, Carlsson M, Ekselius L. Coping strategies, health-related quality of life and psychiatric history in patients with aneurismal subarachnoid haemorrhage. Acta Neurochir 2010; 152(8): 1375-1382. http://dx.doi.org/10.1007/s00701-010-0673-y

[22] Lazarus, RS, Folkman S. Stress, appraisal and coping. New York: Springer Publishing; 1984. p.141-180.

[23] Drageset S, Lindström TC, Underlid K. Coping with breast cancer: between diagnosis and surgery. J Adv Nurs 2010; 66(1): 149-158. http://dx.doi.org/10.1111/j.1365-2648.2009.05210.x

[24] Yilmaz M, Sezer H, Gürler H, Bekar M. Predictors of preoperative anxiety in surgical inpatients. J Clin Nurs. 2011; 21: 956-964. http://dx.doi.org/10.1111/j.1365-2702.2011.03799.x

[25] Buchanan K, Elias LJ, Goplen GB. Differing perspectives on outcome after subarachnoid hemorrhage: the patient, the relative, the neurosurgeon. Neurosurgery 2000; 46(4): 831-840.

[26] Wideheim AK, Edvardsson T, Påhlson A, Ahlström G. A Family’s perspective on living with a highly malignant brain tumor. Cancer Nurs 2002; 25(3):236-244. http://dx.doi.org/10.1097/00002820-200206000-00012

[27] Majasaari H, Sarajärvi A, Koskinen H, Autere S, Paavilainen E. Patients' perceptions of emotional support and information provided to family members. AORN J 2005; 81(5): 1030-1039. http://dx.doi.org/10.1016/S0001-2092(06)60469-9

[28] Rydholm Hedman AM, Strömberg L, Grafström M, Heikkilä K. Hip fracture patients’ cognitive state affects family members’ experiences: a diary study of the hip fracture recovery. Scand J Caring Sci. 2011; 25(3): 451-458. http://dx.doi.org/10.1111/j.1471-6712.2010.00848.x

[29] Kotilainen E, Seitsalo S. Lanneselän välilevytyrän leikkaushoito. [Surgical treatment of lower back intervertebral herniated disc]. Duodecim. 1999; 115: 1743-1748.

[30] Saban K L. Penckofer SM. Patient expectations of quality of life following lumbar spinal surgery. J Neurosci Nurs. 2007; 39(3): 180-189. http://dx.doi.org/10.1097/01376517-200706000-00009

[31] Rosenberger PH, Ickovics JR, Epel ES, D’Entremont D, Jokl P. Physical recovery in arthroscopic knee surgery: unique contributions of coping behaviors to clinical outcomes and stress reactivity. Psychol Health. 2004; 19(3): 307-320. http://dx.doi.org/10.1080/0887044042000193460

[32] Salmon P, Hall GM, Peerbhoy D, Shenkin A, Parker C. Recovery from hip and knee arthroplasty: patients’ perspective on pain, function, quality of life, and well-Being up to 6 months postoperatively. ArchPhysMedRehabil. 2001; 82(3): 360-366. http://dx.doi.org/10.1053/apmr.2001.21522

[33] Rantanen A, Heikkilä A, Asikainen P, Paavilainen E, Åstedt-Kurki P. Perheiden tuen saanti terveydenhuollossa -pilottitutkimus. [Support received by families in health care - a pilot study]. Hoitotiede. 2010; 22(2): 141-152.

[34] Tastan S, Kose G, Iyigun E, Ayhan H, Coskun H, Hatipoglu S. Experiences of the relatives of patients undergoing cranial surgery for a brain tumor: A descriptive qualitative study. J Neurosci Nurs. 2011; 43 (2): 77-84. http://dx.doi.org/10.1097/JNN.0b013e31820c94da

[35] LaMontage LL, Hepworth JT, Cohen F, Salisbury MH. Adolescents' coping with surgery for scoliosis: effects on recovery outcomes over time. Res Nurs Health 2004; 27(4): 237-253. http://dx.doi.org/10.1002/nur.20026

[36] Dropkin M J. Body image and quality of life after head and neck cancer surgery. Cancer Pract. 1999; 7(6): 309-313. http://dx.doi.org/10.1046/j.1523-5394.1999.76006.x

[37] Dropkin M J. Anxiety, coping strategies, and coping behaviors in patients undergoing head and neck cancer surgery. Cancer Nurs. 2001; 24(2): 143- 148. http://dx.doi.org/10.1097/00002820-200104000-00010

[38] Åstedt-Kurki P, Paavilainen E, Tammentie T, Paunonen-Ilmonen M. Interaction between family members and health care providers in an acute care setting in Finland. J Fam Nurs. 2001; 7 (4): 371-390. http://dx.doi.org/10.1177/107484070100700404

[39] Johansson K, Nuutila L, Virtanen H, Katajisto J, Salanterä S. Preoperative education for orthopaedic patients: Systematic review. J Adv Nurs. 2005; 50 (2): 212-223. http://dx.doi.org/10.1111/j.1365-2648.2005.03381.x

[40] Leikkola P, Helminen M, Paavilainen E, Åstedt-Kurki P. Selkäleikkauspotilaiden ja heidän läheistensä selviytymisen voimavarat potilaan kotiutuessa sairaalasta [Back surgical patients' and their family members' coping resources at discharge from hospital]. Tutkiva Hoitotyö; 2013; 11(3): 27-36.

[41] Polit D, Beck C, Hungler B. Essentials of nursing research methods, appraisal and utilization. 5th ed. Philadelphia: Lippincott; 2001: p.449.

[42] Burns N, Grove SK. Understanding nursing research: building an evidence-based practice. 4th ed. Philadelphia: Elsevier Saunders; 2007. p. 390-391. 
[43] Abergel A, Spector S, Khafif A, Fliss DM. Patient, caregiver, and surgeon perceptions of quality of life following anterior skull base surgery. Arch otolaryngol head neck surg 2004; 130 (11): 1276-1281. http://dx.doi.org/10.1001/archotol.130.11.1276

[44] Leikkola P. Neurokirurgisen potilaan ja läheisen selviytyminen leikkauksen jälkeen [Postoperative coping of neurosurgical patients and their family members] [master's thesis]. University of Tampere; 2006. 95 p.

[45] Vehviläinen-Julkunen K, Paunonen M. Kvantitatiivisen tutkimuksen luotettavuus. [Reliability of quantitative research]. In Paunonen M, Vehviläinen-Julkunen K. Hoitotieteen tutkimusmetodiikka [Research methodology in nursing science]. Porvoo, Finland: WSOY; 2006: p. 206-214.

[46] Polit DF, Beck CT. Nursing research: generating and assessing evidence for nursing practice. 8th ed. New York: Wolter Kluwer. Lippincott. Williams \& Wilkins; 2008. p. 449-473.

[47] Polit D, Beck C. Nursing research: appraising evidence for nursing practice. 7th ed. Philadelphia: Lippincott; 2010. p. $413-415$.

[48] Valtakunnallinen sosiaali- ja terveysalan eettinen neuvottelukunta [National Advisory Board on Social Welfare and Health Care Ethics] Shared values in health care, common goals and principles. [Internet]. ETENE publications 1. Ministry of Social Affairs and Health in Finland; 2001[cited 2012 Oct 25]. Available from: http://www.etene.org/dokumentit.shtml. Read 5.5.2012

[49] Burns N, Grove S K. The practice of nursing research: conduct, critique \& utilization. 5th ed. St Louis, MO: Elsevier Saunders; 2005: p. 441-460.

[50] Heikkilä T. Tilastollinen tutkimus [Statistical research] 7th -8th ed. Helsinki, Finland: Edita Prima Oy; 2000. p.66-67. 